\title{
The Analysis of Emission Permits Trading System
}

\author{
Liu Yang \\ South China University of Technology, Panyu District, Guangzhou, Guangdong \\ 452665595@qq.com
}

\begin{abstract}
As one of the economic means of environmental policy, the emission trading system can effectively reduce the environmental load and achieve the purpose of preserving the environment. In China, it's urgent to improve the problem of environmental pollution by establishing a sound emissions trading system. Based on the background of emissions trading, this paper proves the social benefits brought by the emission rights trading through the analysis of economic principles. By comparing the successful experience of the foreign emissions trading system and the implementation of the domestic emissions trading system, it provides some references for establishing a perfect system of emissions trading in China.
\end{abstract}

Keywords: Emissions Trading; Emission right; Emission Permits System; Environmental issues

\section{The Background of Emission Trading Theory}

Enterprises discharge pollutants to the surrounding environment in the production process, such as waste water, waste gas and waste residue, etc. These pollutants exceed environmental self-purification capacity or environmental capacity will destroy the environment, which is external or external diseconomy.

In 1920, the famous British economist Pigou in "welfare economics" pointed out that taxation or charging of polluters can be used to solve the externalities problem. The tax standard should be equal to the external cost of pollution, so that the cost of business is equal to social costs. In this case, the optimal output decision is equal to the optimal output decision, and the pollution level is the lowest in society. This tax is known as Pigovian tax or sewage charges. However, the burden of developing an effective Pigovian tax is so large that it is impossible to calculate an effective Pigovian tax. Therefore, the Pigouvian tax has many shortcomings in practice.

In 1960, the economist Coase pointed out in his famous paper on social costs that pollution needs to be managed. But pollution control will also cause losses to the enterprise. Since commodity exchange can be viewed as an exchange of rights, pollution rights can also be exchanged so that pollution can be most efficiently addressed through market transactions. Later scholars put this thought of Coase as: as long as the market transaction cost is zero, regardless of how the initial property rights allocation, market transactions can always optimize the allocation of resources.

In 1968, Dales applied the Coase Theorem to water pollution control studies. In 1972, Montgomery theoretically proved that the market-based emissions trading system is clearly superior to the traditional environmental management policy. In his view, the advantages of the emissions trading system is the amount of pollution control can be changed according to the cost of governance, so that the total cost of coordination can be the lowest. Therefore, if the emissions trading system replace the traditional sewage charges system, it can save a lot of costs.

\section{The Economic Analysis of Emission Permits}

\subsection{Market Activity Analysis of Emissions Trading}


Emissions trading establish a legal right to discharge pollutants under conditions that meet environmental requirements and to allow such rights to be bought and sold like commodities in order to control the discharge of pollutants. The general approach is: First, the government determines a certain area of environmental quality objectives, and accordingly evaluates the environmental capacity of the region. Then calculate the maximum allowable emissions of pollutants, and the maximum allowable emissions divided into a number of provisions of the emissions. Governments may choose to allocate these rights in different ways, such as open auction auctions, sale pricing or free distribution, and to make such rights legally available through the establishment of markets for emissions trading. In the emission rights market, polluters determine the extent of its pollution from their interests, and then buy or sell the emission rights. Each unit holding the emission allowances index carries out trading activities under the relevant policies and regulations.

\subsection{Individual Micro - economic Analysis of Emission Permits}

The prerequisite for emissions trading is the difference between the marginal costs of pollution control. At the same time, the government's environmental management uses total control. As shown in Fig .1: The abscissa represents the amount of pollutant emission reduction, and the ordinate represents the emission price and the marginal cost. Suppose there are two polluting firms $\mathrm{A}$ and $\mathrm{B} . \mathrm{MC}_{1}$ and $\mathrm{MC}_{2}$ represent the marginal control cost curves for pollutants in enterprises $\mathrm{A}$ and $\mathrm{B}$ respectively. The pollution of enterprise $\mathrm{B}$ is more efficient than that of enterprise $\mathrm{A}$. If $\mathrm{A}$ and $\mathrm{B}$ implement the same emission standards (pollutants required to treat $\mathrm{Q}_{0}$ ) and $\mathrm{Q}_{1} \mathrm{Q}_{0}=\mathrm{Q}_{2} \mathrm{Q}_{0}$. The government determined the initial market price per unit of emission rights as $\mathrm{P}$. As the enterprise A's pollution control costs are greater than the enterprise $\mathrm{B}(\mathrm{MC} 1>\mathrm{MC} 2)$, driven by economic interests, there will be a situation that A pay a certain amount of pollutants in exchange for corporate B to reduce the amount of "Transaction ". A purchases the emission right from B which has not yet reached the emission reduction $\left(\mathrm{Q}_{0}-\mathrm{Q}_{1}\right)$ in the emission rights market (Quadrilateral area of $\left.\mathrm{CQ}_{\mathrm{I}} \mathrm{Q}_{0} \mathrm{~B}\right)$. Accordingly, B sells excess waste reduction $\left(\mathrm{Q}_{2}-\mathrm{Q}_{0}\right)$ to $\mathrm{A}$. Fig .1 shows that when two polluting enterprises have to meet the same amount of pollutant treatment level QO, the overall pollution control costs: $\mathrm{TC}=\mathrm{SOAQ}_{0}+\mathrm{SOBQ}_{0}$. The $\mathrm{SOAQ}_{0}$ and $\mathrm{SOBQ}_{0}$ are the areas of triangle $\mathrm{OAQ}_{0}$ and triangle $\mathrm{OBQ}_{0}$ respectively, representing the pollution control costs of enterprises $\mathrm{A}$ and B. When the two companies to conduct emissions trading, the actual cost of pollution control: $\mathrm{TC}^{*}=\mathrm{S} \triangle \mathrm{OCQI}+\mathrm{S} \triangle \mathrm{ODQ} 2 ; \triangle \mathrm{TC}=\mathrm{TC}-\mathrm{TC}^{*}=\mathrm{S} \triangle \mathrm{OAQ} 0+\mathrm{S} \triangle \mathrm{OBQ} 0-\mathrm{S} \triangle \mathrm{OCQI}-\mathrm{S} \triangle \mathrm{ODQ} 2=\mathrm{S} \triangle$ ACQIQ0-S $\triangle \mathrm{BDQ} 0 \mathrm{Q} 2=\mathrm{S} \triangle \mathrm{ABC}$. Therefore, the overall pollution control costs decreased SABC after the implementation of emissions trading. At this point, the two companies in a balanced trading of emissions rights achieve the optimal allocation of environmental resources.

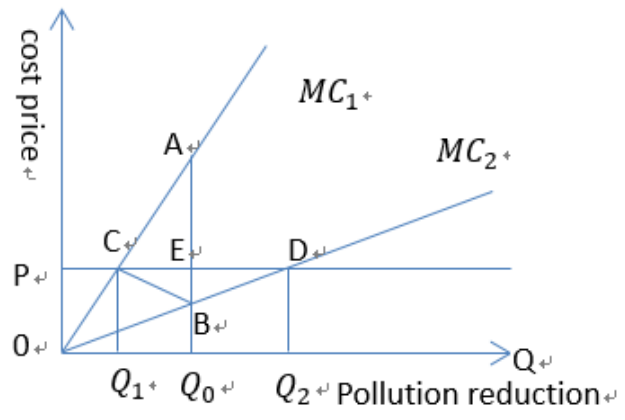

Figure 1. Schemes of Emissions Trading in Two Polluting Enterprises 


\subsection{Advantages of Emissions Trading}

(1) Minimize the cost of governance. As shown in Fig .1, when using the sewage charge policy, the two polluting enterprises to meet environmental standards to achieve the level of pollutant treatment $\mathrm{Q}_{0}$, the overall cost of pollution control decreased ABC. It can be seen that the implementation of emissions trading can be used to seek the marginal cost of pollutant treatment through market forces, thus minimizing the disposal costs of the overall pollutant allowable emissions, with obvious economic benefits.

(2) Improve the production and management of the technical level. Emissions trading not only allow enterprises more flexibility in the choice of governance technology, but also stimulate the development of new technologies. If the cost of improving the production or pollution control technology is greater than the purchase of emission permit index, companies will increase the intensity of technological innovation, and improve their competitiveness. At the same time, because of the increased demand for new technologies, suppliers will be more willing to invest in the development of new technologies. The high degree of initiative of both supply and demand makes the adoption of new technologies more rapid.

(3) Accelerate the improvement of environmental quality and promote economic development. The implementation of emissions trading allows enterprises to better balance economic and environmental benefits, and the government can also through market regulation and control to speed up the improvement of local environmental quality and promote economic development.

\section{The Implementation and Effect of Foreign Emissions Trading System}

\subsection{Emission Permits Trading System in the USA and Its Implementation}

Initially, the USA provides only emissions of sulfur dioxide into the transaction. This is the United States at the time of abatement of pollutant discharge costs. When the United States reduced the cost of 1 ton of sulfur dioxide emissions is 600 US dollars, while the cost of cutting 1 ton of nitrogen oxides is 2,000 to 3,000 US dollars, far higher than the cost of the former. Firstly, the USA provided for a certain period of time the total amount of sulfur dioxide control indicators, then made specific provisions of sulfur dioxide emissions from the facilities and "allowable emissions". For enterprises that exceed the allowable discharge, the government will impose penalties and pay the excess emissions in the following year in order to effectively control the total discharge of the country. For enterprises that have to lag behind technology and facilities to exceed the allowable discharge, they can trade with the other permissible emission holders and specify the specific trading hours. The United States allow enterprises to effectively control the maximum extent of sulfur dioxide emissions through the set and constantly improve the allowable discharge system.

\subsection{Emission Permits Trading System in Germany and Its Implementation}

As a developed industrialized country, Germany energy development and environmental protection has been at the forefront of the world. In early 2002, in order to effectively carry out environmental protection, Germany began to implement carbon emissions trading system. At that time, the German Environmental Protection Agency set up a special management mechanism for enterprise equipment to conduct a comprehensive survey to study the establishment of emissions trading and related legal issues. At present, a comprehensive legal system and management system have been formed, and a special institution for managing emissions trading has also been set up.

\subsection{The global emissions trading market continues to develop and improve}

International carbon emission trading markets include the European Climate Exchange in Amsterdam, the European Energy Exchange in Germany, and the Future Electricity Exchange in 
France. In addition, Japan, Canada, Russia, and Australia also have their own emissions trading market. The Chicago Climate Change Exchange is the world's first domestic climate exchange. In 2014, the transaction volume of carbon trading reached 5553 million tons, the global emissions trade volume has reached 178 billion US dollars.

\section{The Current Situation and Problems of Emission Permits Trading System in China}

\subsection{The Actuality of Emission Permits Trading System in China}

In 1993 the State Environmental Protection Agency began to explore the implementation of the policy of air emissions trading. In 1999, China and the US EPA signed an agreement to carry out the cooperation project of "Using Market Mechanism to Reduce $\mathrm{SO}_{2}$ Emission" in China, taking Jiangsu Nantong and Liaoning Benxi as the earliest pilot bases. In 2001, the first case of sulfur dioxide emissions trading in China occurred in Nantong. In July 2002, the State Environmental Protection Administration held in Shandong, Shanxi, Jiangsu and other "sulfur dioxide emissions trading" seven provinces and cities pilot meeting to further study the deployment of emissions trading pilot specific steps and implementation of the program. The practice shows that as a new environmental economic policy characterized by the role of the market mechanism, the emission trading system can effectively control environmental pollution and play a role in saving the cost of environmental protection and protecting the environment. However, due to the implementation of emissions trading in China soon, there are still many urgent problems to be solved.

\subsection{Problems Existing in Emission Permits Trading System in China}

(1) Difficult to achieve environmental capacity and emissions data monitoring

As a cap of trading emissions, the total amount of emissions is not allowed to exceed the local environmental capacity. So the local environmental capacity of the scientific evaluation and calculation is the first emissions trading needs to be seriously addressed. In emissions trading, environmental management agencies to regulate emissions of pollutants is the most important part. Emission rights require scientific and rational monitoring and supervision. However, China's environmental capacity and emissions data monitoring system is not perfect, resulting in the phenomenon of enterprises to steal. The implementation of emissions trading system encountered obstacles.

(2) The distribution system of emission rights is not clear

The initial allocation of emission rights is the prerequisite for the operation of emission trading market. Reasonable allocation of the initial emission allowances can achieve the maximum economic benefits under the premise of controlling the total amount of pollutants discharged, thereby inspiring the pollutant discharge unit to improve the prevention and control of pollution, and forming a industrial structure group with low environmental pollution and high productivity and realizing the synchronous development of economic society and environmental protection. The existing methods of distribution abroad are the government free distribution and paid distribution of the main. China has not yet established a specific distribution.

(3) The laws and regulations of emissions trading are not perfect, and the relevant market mechanism is imperfect

In fact, due to the lack of legislation in China, whether the emission rights "transaction" in the academic world is still being questioned. In China, the sewage discharge permit is an administrative license, and administrative licensing is not traded, otherwise there will be "suspected of trading power." In other words, our country has not established the concept of emissions trading in the law, so companies do not get the so-called pollutant emissions of property rights. Emissions trading and administrative licensing law is contradictory, resulting in an awkward situation. 


\section{Measures to Improve the Tradable Emission Permits in China}

\subsection{Accelerate the establishment and improvement of relevant laws and regulations system}

Only with the legal recognition and protection, a system can be effectively established and implemented. Although China's current environmental laws impose a total control and licensing system for pollutants, and have piloted emissions trading in some areas, there is still a lack of more universal and effective laws and regulations to protect and Recognized.

\subsection{Promote healthy development of the market and the rational allocation of resources}

As mentioned above, the internalization of externalities is an important measure to solve environmental problems. With the laws and regulations as a guide and market demand and distribution as the direction, we should cultivate the secondary market for emissions trading, so that the existing emissions trading gradually out of the shadow of official trade, the gradual realization of emissions trading market in order to promote emissions rights in a healthy development of the trading market. As the starting point of emission trading market, the initial distribution of emission rights is related to the benign competition and growth of the market. Government-led distribution of emission rights to achieve a fair distribution of the secondary market is an important prerequisite for ensuring the normal operation of the secondary market. The state should implement policies to regulate emission rights and clarify the powers and responsibilities of the government, establish a scientific quota distribution system, and resolutely put an end to the resulting corruption and fraud, in order to achieve fair, just and open distribution, to achieve dynamic, benign Healthy emissions trading market.

\section{References}

[1] Zhu Haoyu, Chen Xu. Status Quo and Improvement of Corporate Participation of Emissions Trading in China [J]. China Soft Science,2012(6): 15 - 23.

[2] Feng Kaidong, Wu Shu, Zhang Guolin. Theories and Practices for Establishing the Chinese Transaction System for Effluent Discharge Permits [J]. Comparative Economic \& Social Systems, 2013(2):205-215.

[3] Wang Zhenhua. Study on the Problems and Countermeasures of Emissions Trading Implementation [D]. Chongqing University, 2015.

[4] He Jin, Zhang Wen. Economic Analysis of Emission Trading System in China [J]. Modern Business Trade Industry, 2010, 22(2):52-53.

[5] Liu Xue. Analysis of Law and Economics in Emission Permits Trading System [J]. Contemporary Economics, 2016(1):98-99.

[6] Wang Qiang, Jiang Rui. Development of China Pollution Rights Trading and Present Problems [J]. Environmental Science and Management, 2014, 39(6):77-81.

[7] Chang Chao. Design and Practice of Emission Trading System in China [M]. China Environment Press, 2014.

[8] Li Dongdong, Yang Jingyu. The optimal abatement R\&D subsidy based on emission trading [J]. Studies in Science of Science, 2015, 33(10):1504-1510.

[9] Information on http://www.gov.cn/zhengce/content/2014-08/25/content_9050.htm

[10] Zhou Ying. Study on the Current Situation and Existing Problems of Emission Trading in China [J]. Productivity Research, 2014(4):105-108. 